\title{
Isolation of antagonistic Trichoderma spp. against selected phytopathogenic fungi from the field soils in Kelantan
}

\author{
Laila Naher $^{1,2_{\star}}$, Nurul Hazreen ${ }^{1}$, Nor Aqilah ${ }^{1}$, Siti Aminah Binti Mohamed Zaini ${ }^{1}$, Shafiquzzaman Siddiquee $^{3}$ \\ ${ }^{1}$ Faculty of Argo-based Industry, Universiti Malaysia Kelantan, Jeli Campus, Kelantan, 17600, Malaysia. \\ ${ }^{2}$ Institute of Food Security and Sustainable Agriculture, Universiti Malaysia Kelantan, Jeli Campus, 17600, Kelantan, \\ Malaysia. \\ ${ }^{3}$ Biotechnology Research Institute, Universiti Malaysia Sabah, Jalan UMS, Kota Kinabalu, Sabah, Malaysia. \\ Email: lailanaher@umk.edu.my
}

Received 27 June 2016; Received in revised form 28 July 2016; Accepted 1 August 2016

\begin{abstract}
Aims: Trichoderma is a soil borne mycoparasitic fungus which comprises a number of fungal strains that act as biocontrol agent. In this present study have investigated the diversity of Trichoderma in different cultivated soils in state of Kelantan. The effectiveness of biocontrol agent of isolated Trichoderm species was evaluated against the phytopathogen of Pyricularia oryzae, Fusarium oxysporum, and Ganoderma boninense.

Methodology and results: The identification experiment was carried out on the basis of morphological characteristics as colony appearance, shapes and size of conidia, the branching patterns of conidiophores and phialides. Then, the effectiveness of biocontrol agent of Trichoderma species against the pathogens was tested in plate assay experiment. A total of 11 isolates were obtained from three different cultivated soils from Jeli $(\mathrm{J})$, Machang $(\mathrm{M})$ and Pasirmas $(\mathrm{P})$. Morphological studies data identified as two groups of Trichoderma species as Trichoderma harzianum, and T. koningii. All the isolates showed the antagonistic activity against the pathogens while $T$. harzianum strain THMPA1 showed highest antagonistic activity of $80.00 \%$ against $P$. oryzae and in $T$. koningii strain TKMPA3 group showed highest antagonistic activity of $69 \%$ against $P$. oryzae.

Conclusion, significance and impact of study: Among the 11 isolates of Trichoderma, the species of $T$. harzianum strain THMPA1 was the best as biocontrol agent against $P$. oryzae. Thus, diversity of Trichoderma species study is important to find promising species isolation of Trichoderma species which will be influenced in future to sustainable crop production and maintain green environment.
\end{abstract}

Keywords: Biocontrol, Trichoderma, Ganoderma boninense, Fusarium oxysporum, Pyricularia oryzae

\section{INTRODUCTION}

Biological diversity (biodiversity) encompasses the variety of life forms occurring in nature. According to Hawksworth (2001), fungi are a major component of biodiversity, essential for the survival of other organisms and are important in global ecological processes. Fungi are important in the decomposition of plant debris because of their ability to derive carbon and energy requirements from the breakdown of dead and decaying plant cell walls, cellulose and lignin (Lynd et al., 2002). The saprophytic fungal species of Trichoderma can frequently found in agricultural soils for involving carbon fixation in soil during the process of decomposer. The fungus is fast growing as well as competitive nature compare to other fungi and produced hydrolytic enzyme to hydrolyse substrates from soil; with these characteristics make Trichoderma as good decomposer. Thus, the diversity of Trichoderma is an important factor in soil as well as for agriculture. Besides, the role as decomposer the genus of Trichoderma also act as biocontrol agent against many phytopathogens (Srivastava et al., 2015). Besides, the beneficial effects of fungus are many fungi also affect the agriculture production and economy. Like, Pyricularia oryzae, which caused leaf blast disease in rice (Suryadi et al., 2013). The disease result in yield loss and subsequently reduce the seed quality (Hai et al., 2007). While, the fungus Fusarium oxysporum is a phytopathogenic for several plants including banana plant which is usually call Panama disease. Panama disease is the most highly destructive disease affecting commercial and subsistence of banana production throughout the banana producing areas of the world (Ploetz and Pegg, 2000; Monila et al., 2009). Ganoderma boninense cause basal stem rot (BSR) disease in oil palm (Elaies guineesis Jacq) (Fee, 2011). Ganoderma boninense is a threat for palm oil industry (Naher et al., 2015). Above mentioned all the pathogens controlled by chemical treatment. Due to 
environment concern the chemical approach is not ecofriendly. Using biocontrol approach is an eco-friendly option which control the pathogen without the negative effect on the plant and environment. Thus, this study was determined to identify natural resource of species diversity of Trichoderma from local cultivated soil and evaluated the biocontrol effectiveness against Pyricularia oryzae, Fusarium oxysporum and Ganoderma boninense.

\section{MATERIALS AND METHODS}

\section{Sample collection}

The soil samples were collected from different cultivated soils at Jeli, Machang, and Pasirmas, Kelantan state in Malaysia. The soil samples were randomly taken at the depth of $10 \mathrm{~cm}$ from four cardinal points of each cultivated fields of chili, pineapple, and rice by using a cock borer. From this soil core, approximately $200 \mathrm{~g}$ of the soil samples were taken out and kept in the polyethylene bags, sealed in boxes and labeled with the information of the collection sites. Then, the labeled samples were stored set at $4{ }^{\circ} \mathrm{C}$.

\section{Isolation of fungi by soil dilution technique}

A $10 \mathrm{~g}$ of soil was weighed from $200 \mathrm{~g}$ of soil sample for each site. The isolation of fungi was done by mixing $10 \mathrm{~g}$ of soil sample with $100 \mathrm{~mL}$ of distilled water in a conical flask. After mix the soil with water, the conical flasks were covered with aluminium foil before agitated in electrical shakers (Jeio Tech, Korea) at $100 \mathrm{rpm}$ for $10 \mathrm{~min}$. Serial dilution technique was used to isolate the fungi from soil. Soil serial dilution was carried out using $1 \mathrm{~mL}$ of soil suspension and $9 \mathrm{~mL}$ of distilled water conducted up to different serial dilutions of $10^{-1}, 10^{-2}, 10^{-3}, 10^{-4}$ and $10^{-5}$ in final volume of $10 \mathrm{~mL}$ and from there $1 \mathrm{~mL}$ of diluted soil was poured into the petri dish which previously contained Dichloran Rose Bengal Chloramphenicol (DRBC) media. DRBC media was prepared as $5.00 \mathrm{~g}$ of Peptone, $10.00 \mathrm{~g}$ of Dextrose, $1.00 \mathrm{~g}$ of potassium phosphate, $0.50 \mathrm{~g}$ magnesium sulfate, $0.05 \mathrm{~g}$ of Rose bengal, $15.00 \mathrm{~g}$ of agar of the constituent were added into $500 \mathrm{~mL}$ of distilled water in the conical flask. The experiment was conducted in three replicates. The dilution plate was observed daily for the 7 days to examine the diversity of the fungus. After the 7 days, the yellowish green with the same growth appearance of the colonies were selected as Trichoderma sp. for culture on PDA plate. Then, slide culture technique (Johnson, 1946) was used for the observation and identification of Trichoderma sp. A thin section of PDA agar containing the fungus was fixed on microscopic slide which was cover with the coverslip and the slide was observed under the light microscope for identification of Trichoderma species.

\section{Morphological identification}

Trichoderma species identification were performed based on morphological anatomy according to Gams and Bissett
(2002) and using interactive key for strain identification at http://nt.ars-grin.gov/taxadescriptions/keys/Trichodermaln dex.cfm. Identification of macro-morphological characteristics were analysed by: colony colour, mycelium density, growth rate and pattern. While the micromorphological characteristics analysed as: the size, shape and color of the conidia, the branching pattern of the conidiosphore, the presence of chlamydospores and phialides.

\section{Pure culture of the pathogen}

Three pathogens of Ganoderma boninense (Pat.), Fusarium oxysporum (f. sp. cubense), and Pyricularia oryzae (Cavara) were collected from the slant stock culture. Each fungus of a thick mycelium agar disc was taken from stock culture by using sterile loop and then placed into a Petri dish contained PDA. The culture was stored at the room temperature $\pm 28{ }^{\circ} \mathrm{C}$ for full colony growth.

\section{Antagonistic activity of isolated Trichoderma sp. against pathogen}

A $6 \mathrm{~mm}$ diameter agar disc of pathogen was taken from the edge of actively growing pure culture and placed $1 \mathrm{~cm}$ inside from the edge of PDA containing petri dish as size of $8.8 \mathrm{~cm}$. The samples were allowed to grow for 3 days by which time the colony will be reaching to $2 \mathrm{~cm}$. Then a $6 \mathrm{~mm}$ diameter disc was taken from pure culture of isolated Trichoderma sp. and then placed on the opposite site of petri dish containing each pathogen separately, while control plate was contained only pathogen. The experiment was conducted for 5-7 days. Finally, the antagonistic activity of the Trichoderma sp. was be measured by using the formula of Percentage Inhibition of Radial Growth (PIRG).

$$
P I R G=\frac{R 1-R 2}{R 1} \times 100
$$

Where PIRG = Percentage Inhibition of Radial Growth $\mathrm{R} 1$ = the radial growth of the $G$. boninense, $F$. oxysporum and $P$. oryza in the absence of the isolated Trichoderma spp. (control plate)

$\mathrm{R} 2$ = the radial growth of the $G$. boninense, F. oxysporum and $P$. oryza in the presence of the isolated Trichoderma spp.

\section{RESULTS}

\section{Isolation of Trichoderma colony}

A total of 100 fungal isolates were successfully isolated from soil samples that were collected from cultivated soils in Jeli, Machang and Pasirmas in the state of Kelantan. About 20 of colonies as Trichoderma out of 200 microbial colonies were selected based on morphological appearance on RBA media. After that, isolates were 
screened based on the similarity of the colony appearance and 11 colonies were selected as Trichoderma species for morphological studies.

\section{Morphological analysis}

Specific identification by morphology

Differences in macro- and micromorphological characteristics of the Trichoderma species was summarized in Table 1. This includes the distinct differences on morphological characteristics of Trichoderma species which are the shape of phialospores, shape of phialides and branching of conidiospores. Based on the observation of seven colonies, this study found two different types of Trichoderma species which were $T$. harzianum and $T$. koningii.

Table 1: The macro- and micromorphological characteristics of T. harzianum and T. koningii.

\begin{tabular}{|c|c|c|c|c|c|c|}
\hline Species & $\begin{array}{l}\text { Isolate } \\
\text { Code }\end{array}$ & Phialides & Conidio-phores & Phialospores & $\begin{array}{l}\text { Chlamydo- } \\
\text { spores }\end{array}$ & $\begin{array}{l}\text { Colony } \\
\text { Color on } \\
\text { PDA }\end{array}$ \\
\hline T. harzianum & $\begin{array}{l}\text { THMPA1 } \\
\text { THMPA2 } \\
\text { THPPA4 } \\
\text { THJVT1 } \\
\text { THJVT2 } \\
\text { THJVT3 }\end{array}$ & $\begin{array}{l}\text { Cylindrical; } \\
\text { enlarge in the } \\
\text { middle }\end{array}$ & $\begin{array}{l}\text { Paired branches } \\
\text { along the main } \\
\text { axis }\end{array}$ & $\begin{array}{l}\text { Subglobose to } \\
\text { short obovoid }\end{array}$ & $\begin{array}{l}\text { Globose; } \\
\text { granulate }\end{array}$ & $\begin{array}{l}\text { Whitish } \\
\text { green to dull } \\
\text { green }\end{array}$ \\
\hline T. koningii & $\begin{array}{l}\text { TKMPA3 } \\
\text { TKMPB4 } \\
\text { TKPPA1 } \\
\text { TKPPB2 } \\
\text { TKPPB3 }\end{array}$ & $\begin{array}{l}\text { Narrower at the } \\
\text { base and } \\
\text { tapering toward } \\
\text { apex }\end{array}$ & $\begin{array}{l}\text { Branched and } \\
\text { erects }\end{array}$ & $\begin{array}{l}\text { Oblong to } \\
\text { narrowly } \\
\text { ellipsoidal }\end{array}$ & - & $\begin{array}{l}\text { Whitish } \\
\text { green to } \\
\text { dark green }\end{array}$ \\
\hline
\end{tabular}
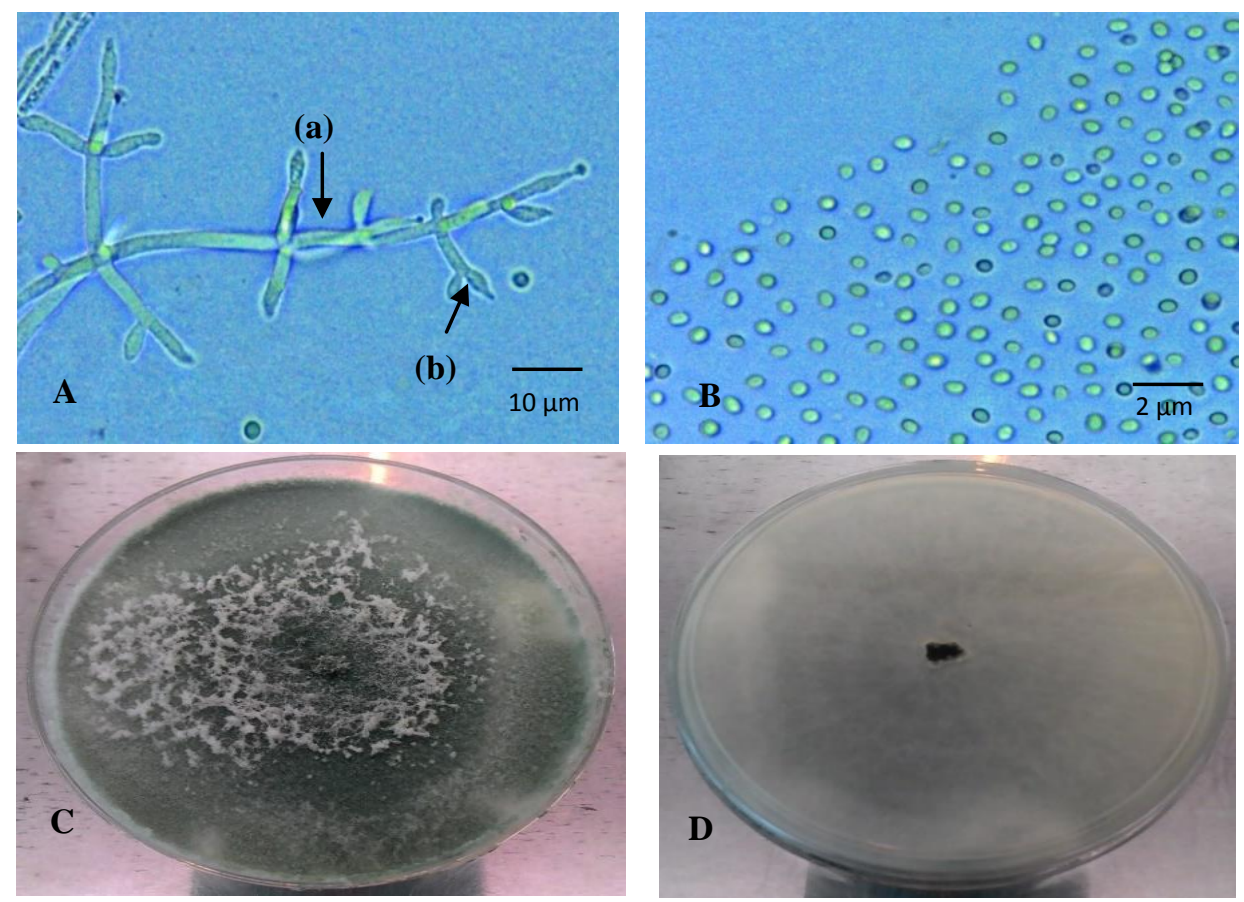

Figure 1: Morphological characteristics of T. koningii. A, the branches of conidiophores (arrow a), Phialides (arrow b); B, phialospores; $\mathrm{C}$, colony features from front view on PDA; $\mathrm{D}$, reverse side of the culture plate.

\section{Morphological characteristic of Trichoderma koningii}

Five out of 11 colonies were identified as Trichoderma koningii. The morphological characteristics are shown in
Figure 1. The conidiophores of $T$. koningii was observed as branched and erects [Figure 1A (a)] typically consisting of a strongly developed central axis with a very uniform branching pattern. The phialides were mainly arranged in 
divergent whorls of two to three which arise at or near the tip of the main axis. The shape of phialides was somewhat swollen and flask-shaped, narrow at the base and tapering toward apex [Figure 1A (b)]. The phialospores of $T$. koningii were oblong to narrowly ellipsoidal shape with the size of $2 \mu \mathrm{m}$ as shown in Figure 1B. The colony appearance shown that the colours changed slowly from whitish green to greenish green, and
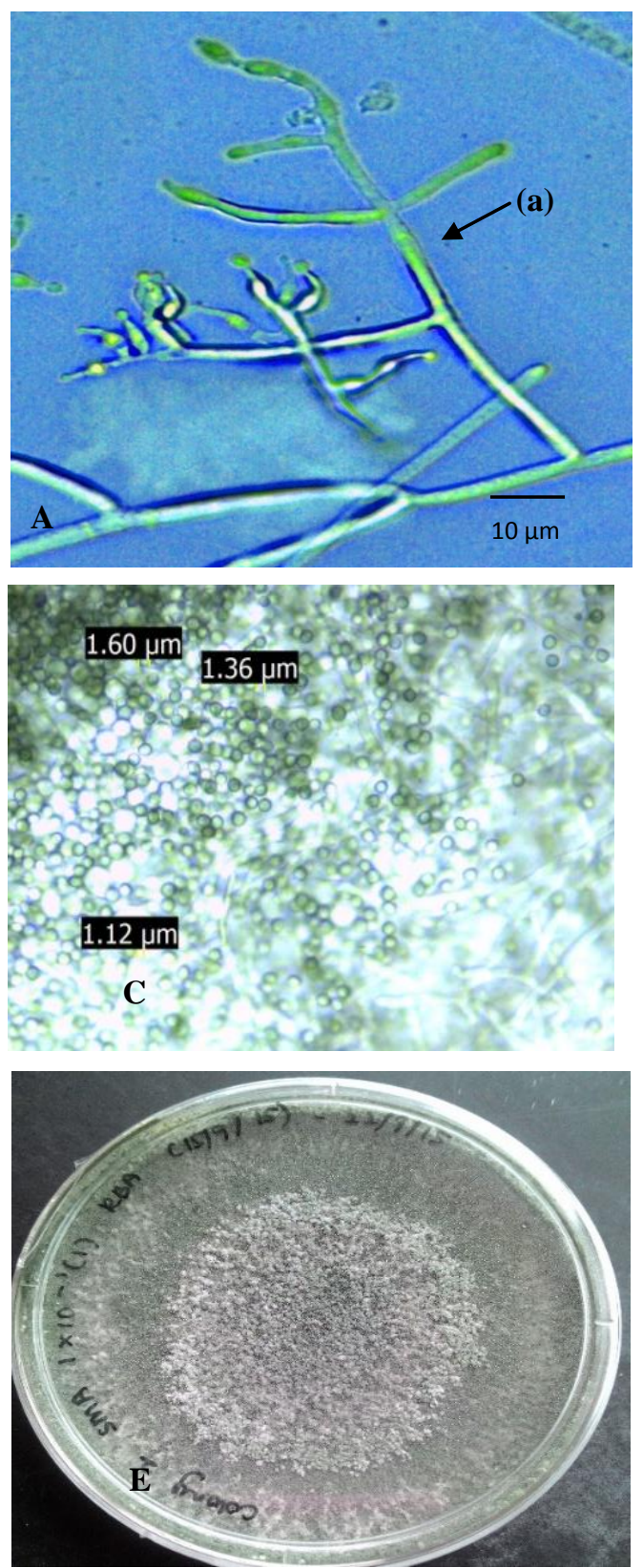

finally to dark green (Figure $1 \mathrm{C}$ ) and the reverse side or bottom of the culture showed no pigmentation on the PDA (Figure 1D). Besides, the colony of $T$. koningii formed moderately well concentric rings with compact to rather loose tuft texture. The growth rate of the $T$. koningii colonies on PDA at room temperature were considerably high ranging between $1.6-2.6 \mathrm{~cm} /$ day and the mycelia may covered the whole plate within five days.
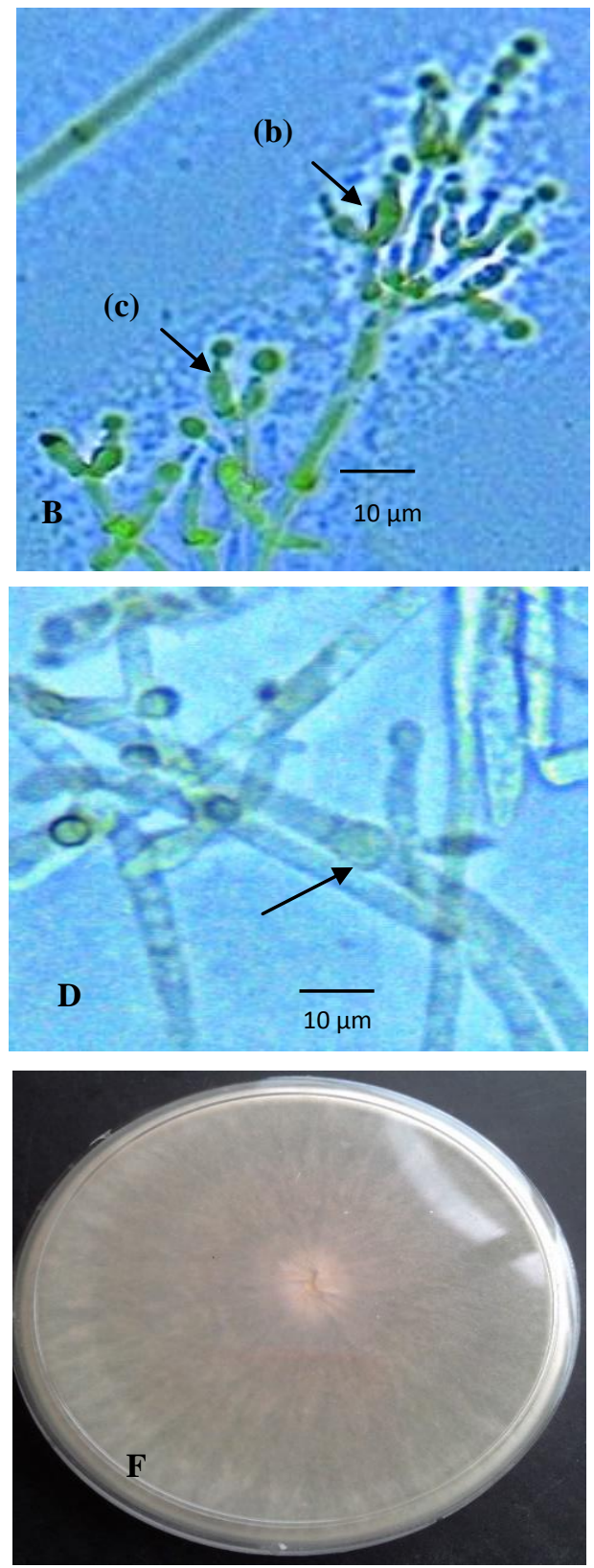

Figure 2: Morphological characteristics of T. harzianum (isolate THMPA2). A, the branches of conidiophores (arrow a); $B$, phialides (arrow b, c); C, phialospores; D, chlamydospores; $E$, colony features from front view on PDA; $F$, reverse side of the culture plate. 


\section{Morphological characteristic of Trichoderma harzianum}

Six colonies were identified as $T$. harzianum. All the morphological characteristics are shown in Figure 2. The formation of conidiophores in $T$. harzianum was in the form of paired branches along the main axis as in Figure $2 \mathrm{~A}$. Their phialides generally bends towards the apex with the form of cylindrical shape which enlarge in the middle (Figure 2B). The phialospores shapes of the T. harzianum were subglobose to short obovoid and the spore size which is from $1.0 \mu \mathrm{m}$ to $1.6 \mu \mathrm{m}$ as shown in Figure $2 \mathrm{C}$. Moreover, $T$. harzianum produced granulated chlamydospores with a globose shape (Figure 2D). The colonies appearance of $T$. harzianum were whitish green to dull green in color and (Figure 2E) with no pigmentation produced through the PDA (Figure $2 \mathrm{~F}$ ). In addition, the colonies form 1-2 concentric rings of conidial zone on the surface of the colony and it was composed of rather lose or compact tufts. Colonies of $T$. harzianum grew rapidly on PDA at room temperature with growth rate ranged between $2.1-3.2 \mathrm{~cm} /$ day and cover the whole plate within four days.

\section{Antagonistic activity of isolated Trichoderma spp.}

The antagonistic effect of all Trichoderma isolates were tested against pathogenic fungi, of $P$. oryzae, $G$. boninense and $F$. oxysporum on PDA at room temperature for seven days. The percentage inhibition of radial growth (PIRG) of all three pathogens by Trichoderma spp. are presented in Table 2. The study found highest antagonistic activity in T. harzianum MPA1 with the inhibition percentage of $86.04 \%$ against $P$. oryzae. The second highest antagonistic activity of $71.09 \%$ observed in $T$. harzianum MPA1 against the same pathogen of $P$. oryzae, while in species of

Table 2: Antagonistic activity of selected Trichoderma isolates against three causal pathogens of Pyricularia oryzae, Fusarium oxysporum and Ganoderma boninense.

\begin{tabular}{lll}
\hline Species Name & PIRG in \% & Pathogens \\
\hline T. harzianum MPA1 & 86.04 & P. oryzae \\
T. harzianum MPA2 & 71.09 & P. oryzae \\
T. koningii MPA3 & 69.57 & P. oryzae \\
T. koningii MPB3 & 69.57 & P. oryzae \\
T.harzianumJV1 & 53.74 & F. oxysporum \\
T. harzianumJV2 & 54.7 & F. oxysporum \\
T. harzianumJV3 & 57.26 & F. oxysporum \\
T. harzianumPA4 & 60.86 & G. boninense \\
T. koningiiPB4 & 59.00 & G. boninense \\
T. koningiiPB2 & 59.33 & G. boninense \\
T. koningiiPA1 & 45.00 & G. boninense \\
\hline
\end{tabular}

Trichoderma koningii, the highest antagonistic activity of $69.57 \%$ was found in both of $T$. koningii MPA3 and $T$. koningii MPA4. All of these isolates were isolated from Pasirmas, Kelantan. This study noted that all the highest antagonistic activities were found in those isolated from Pasirmas cultivated soil among the other two places of
Jeli and Machang. The second highest antagonistic activity observed in those isolated from Jeli cultivated soil and then lowest was from Machang cultivated soil. The reason is not clear why the isolated strains showed some different activities intensity although all three locations were the same state of Kelantan area. According to Tronsmo and Dennis (1978) reported that temperature affect the growth of Trichoderma species and also their metabolic activity especially the production of volatile antibiotics and enzymes which involving in the process of mycoparasitism activity. This current study only focused on antagonistic activity from the selected isolated Trichoderma species, no data have been recorded from Jeli, Pasirmas and Machang in terms of difference between the temperatures of this three locations.

\section{DISCUSSION}

Trichoderma is soil borne fungus, in this study all isolated fungus obtained from soil in three different locations. Trichoderma is a facultative saprophytic fungus whereby the saprophytic fungus is typically a soil fungus (Srivastava et al., 2015). Soil dilution plate technique was used to isolate of Trichoderma colony, which is good technique for soil fungus. For the isolation and identification of fungus, it is important to use soil dilution technique with proper media. This study used DRBC media to isolate Trichoderma colony from soil. DRBC media contained Rose Bengal dye that functions as antibiotic to inhibit bacterial growth when isolate fungal colony from soils (Himedia, 2011). About 200 colonies were grown in culture plates. Based on the morphological features such as colour appearance, colony growth it was suspected that 20 colonies as Trichoderma. Slide culture was used as for anatomical study for identification of the fungus. Slide culture method is suitable technique for microbial identification. Since 1969, morphological characteristics have been used to characterize and distinguish Trichoderma species (Rifai, 1969; Gams and Bissett, 2002). There were two species as T. harzianum and $T$. koningii were positively identified in the group of Trichoderma species (Table 1). The hyphal branching patterns of these two species (Figure 1 and 2) were different which showed the difference between the species. The branching formation of conidiophore difference is one of distinguish characteristics for species identification (Samuels et al., 2002).

Trichoderma species not only decomposer in soil, they are also a good biocontrol agent against many plant pathogen (Harman et al., 2006). John and the colleagues had found that Trichoderma sp. controlled the pathogens of Fusarium oxysporum and Pythium sp. (John et al., 2010). Thus, in our study, the antagonistic activity of some selected isolates of Trichoderma species of $T$. harzianum and $T$. koningii against the pathogenic species of $P$. oryzae, $F$. oxysporum, and $G$. boninense was evaluated and we had found that the activity of $T$. harzianum strain THMPA1 against $P$. oryzae is the highest which is about $86.04 \%$. Gouramanis (1997) found that $T$. harzianum (GPO-80) inhibited the mycelial growth 
of $P$. oryzae about $71 \%$ and conidial germination about $88 \%$. In another study, the endophytic fungi of Phaialemonium curvatum and Phaeosphaeriopsis musae were found to be inhibiting the growth of $P$. oryzae about $66.6 \%$ and $63.3 \%$, respectfully (Suada et al., 2012).While, the isolated of $T$. harzianum strains JV1, 2, 3 showed the antagonistic activities against $F$. oxysporum and $T$. koningii strains TK PB4, PB2 showed the antagonistic activities against $G$. boninense. Though the antagonistic activities were in the range of $50 \%$, according to Soytong (1988) suggested that that more than $50 \%$ of PIRG is considered as a good biocontrol agent. In conclusion, $T$. harzianum MPA1 was found to be the best against $P$. oryzae.

\section{ACKNOWLEDGMENT}

The authors would like to thank Permohonan Skim Geran Penyelidikan Jangka Pendek (sgjp) (JPPPU) Bil.1/2015 grant for financial support and the reviewer for critically review this paper.

\section{REFERENCES}

Fee, C. G. (2011). Management of Ganoderma diseases in oil palm plantations. The Planter 87, 325-339.

Gams, W. and Bissett, J. (2002). Morphology and identification of Trichoderma. In: Trichoderma and Gliocladium: Basic Biology, Taxoomy and Genetics. Kubicek, C. P. and Harman, G. E. (eds.). Taylor and Francis, USA. pp. 3-31.

Gouramanis, D. G. (1997). Biological and chemical control of rice blast disease (Pyricularia oryzae) in Northern rice. CIHEAM 15, 61-68.

Hai, L. H., Kim, P. V., Du, P. V., Thuy, T. T. T. and Thanh, D. N. (2007). Grain yield and grain-milling quality as affected by rice blast disease (Pyricularia grisea), at My Thanh Nam, Cai Lay, Tien Giang. Omonrice 15, 102-107.

Harman, G. E. (2006). Overview of mechanisms and uses of Trichoderma spp. Phytopathology 96, 190-194.

Hawksworth, D. (2001). The magnitude of fungal diversity: The 1.5 million species estimate revisited. Mycological Research 12, 1422-1432.

HIMEDIA. (2011). Rose Bengal Agar. Technical Data. Available from http://www. himedialabs.com/TD /M842. [Retrieve on July 2016].

John, R. P., Tyagi, R. D., Prévost, D., Brar, S. K., Pouleur, S. and Surampalli, R. Y. (2010). Mycoparasitic Trichoderma viride as a biocontrol agent against Fusarium oxysporum f. sp. adzuki and Pythium arrhenomanes and as a growth promoter of soybean. Crop Protection 29, 1452-1459.

Johnson, E. A. (1946). An improved slide culture technique for the study and identification of pathogenic fungi. Journal of Bacteriology 51, 689-694.

Lynd, L. R., Weimer, P. J., Van Zyl, W. H. and Pretorious, I. S. (2002). Microbial cellulose utilization: Fundamentals and biotechnology microbiology. Microbiology Molecular Biology Review 66, 506-577.
Molina, A. B., Fabregar, E., Sinohin, V. G., Yi, G. and Viljoen, A. (2009). Recent occurrence of Fusarium oxysporum f. sp. cubense Tropical Race 4 in Asia. In: Proceedings of the international ISHS-ProMusa symposium on recent advances in banana crop protection for sustainable production and improved livelihood held in white river, South Africa. Jones, D. R. and Van den Bergh, I. (eds.). ISHS, Leuven, Belgium. 828, $109-116$.

Naher, L., Siddiquee, S., Yusuf, K. U. and Mondal, M. M. A. (2015). Issues of Ganoderma spp. and basal stem rot disease management in oil palm. American Journal of Agricultural Science 2, 103-107.

Soytong, K. (1988). Identification of species of Chaetomium in the Philippines and screening for their biocontrol properties against seed borne fungi of rie. Ph.D. Thesis. ULPB College, Philippines.

Srivastava, M., Pandey, S., Shahid, M., Kumar, V., Singh, A., Shubha, T., Maury, K. M. and Srivastava, K. Y. (2015). Biocontrol mechanisms evolved by Trichoderma sp. against phytopathogens: A review. The Bioscan 10, 1713-1719.

Suada, K., Suhartini, Y. W. M. D., Sunariasih, L. P. N., Wirawan, P. G. I., Chum, W. K., Cha, Y. J. and Ohga, S. (2012). Ability of endophytic fungi isolated from rice to inhibit Pyricularia oryzae-induced rice blast in Indonesia. Journal of Faculty of Agriculture Kyushu Univeristy 57, 51-53.

Suryadi, Y., Susilowati, D. N., Riana, E. and Mubarik, N. R. (2013). Management of rice blast disease (Pyricularia oryzae) using formulated bacterial consortium. Emirates Journal of Food and Agriculture 25, 349-357.

Ploetz, R. C. and Pegg, K. G. (2000). Fusarium wilt. In: Diseases of Banana, Abacá and Enset. Jones, D. R. (ed.). CABI Publishing, Wallingford, UK. pp. 143-159.

Rifai, M. A. (1969). A revision of the genus Trichoderma. Mucological Papers 166, 1-56.

Samuels, G. J., Dodd, S. L., Gams, W., Castlebury, L. A. and Petrini, O. (2002). Trichoderma species associated with the green mold epidemic of commercially grown Agaricus bisporus. Mycologia 94, 146-170.

Tronsmo, A. and Dennis, C. (1978). Effect of temperature on antagonistic properties of Trichoderma species. Transactions of the British Mycological Society 71, 469-474. 